\title{
The Effect of Using Word Wall Picture Media and Linguistic Intelligence to Enhance Learning Outcomes of English Vocabularies
}

\author{
Marhamah Marhamah \\ Mulyadi Mulyadi \\ Post Graduate of Educational Science, \\ Islamic University of Jakarta, Indonesia
}

Doi: 10.36941/jesr-2020-0033

\begin{abstract}
This study focused on investigating the effect of word wall picture on the fourth grade Elementary School in learning outcomes of English vocabularies. The experimental method used in this study and the participants were 98 fourth grade elementary school of Al-AzharSyifa Budi,Bekasi, Eastern Jakarta, Indonesia academic year 2016-2017, as well as samples with a stratified random technique based factorial design that was selected group of students. The data were analyzed using statistical program SPSS 21.0 for descriptive analysis and inferential analysis with ANOVA two lanes to test the hypothesis followed by Tukey's test. The results showed that: 1) there was a significant difference in learning outcomes of English vocabularies between students who taught by using word wall picture and students taught by using printed media. 2) there was an interaction in learning outcomes of English vocabularies on a test comprised of "linguistic intelligence" between students who taught by using word wall picture and students taught by using printed media .3) there was higher learning outcomes of English vocabularies for higher linguistic intelligence students who taught by using word wall picture than students taught by using printed media. 4) there was lower learning outcomes of English vocabularies for lower linguistic intelligence students who taught by using word wall picture than students taught by using printed media. Based on these findings it can be concluded that the word wall picture is effective to improve learning outcomes of English vocabularies, and to enhance linguistic intelligence.
\end{abstract}

Keywords: Word wall picture, Printed Media, Linguistic Intelligence, Learning outcomes, vocabularies

\section{Introduction}

The development of science and technological requires qualified human resources to be able to compete with other nations and can face the challenges of the times. Improving the quality of education becomes one of the most important factors related to efforts to improve human resources. To achieve this, it is necessary to have an integrated education system of all units and educational activities that relate to the achievement of the educational objectives.

The learning process in elementary school is the initial momentum for students to improve their ability. Education is believed to be able to instill experience, knowledge, and skills so as to obtain productive individuals who have excellent potential and can solve the life problems.

In the world of education, language is the key to determine success in learning. English is an international language that is used in almost all parts of the world. English is a tool for communicating both orally and in writing. It serves as a tool for communication in order to access information and to foster interpersonal relationships, exchange information and enjoy the aesthetics of language in English culture. In the mastery of speaking, reading, writing, and listening, of course, students should master vocabulary. One component of language learning is the understanding of the vocabulary of the English language itself, in addition to the other components. 
In accordance with the demands of achieving the goals of learning English, which can communicate both orally and in writing, the students are required to have adequate vocabulary so that they can communicate well in various contexts. Mastery of vocabulary is the most fundamental thing that must be mastered by someone in learning English. How one can express a language if he does not understand the vocabulary of the language.

The reality that occurred in the field shows that the implementation of English learning is still many weaknesses and shortcomings, according to Kasihani (2007) many students just sit, look and listen to the material that has been verbally delivered by the teacher. Teachers feel that using conventional methods in teaching will be easier to supervise, control and direct students, but the students tend to become passive and less able to develop the potential that exists.

To overcome these problems, it needs support from all parties and hard work of teachers in using a variety of media in accordance with the environment and linguistic intelligence of students, especially in learning English. In order to get maximum learning vocabulary results, a teacher must know the level of linguistic intelligence that each student has. One of the important factors in learning English is teachers who care about the needs of their students.

In learning English, teachers should be able and try to make the students can use the correct and appropriate vocabulary in speaking and in writing. Through the use of teaching aids or media teachers can assist students in improving learning vocabulary. A good media is a medium that involves students' activeness in their use.

A teacher is in charge of presenting a precise, clear, interesting, and efficient teaching. This is done by using a variety of media so that students are more interested and eager in learning English. Development and use of instructional media is a necessity that must be prepared and done by teachers in learning activities. Teachers are at the forefront of successful learning activities in schools that are directly involved in planning and carry out learning activities. One of them is by applying word wall picture media. By using this media students are expected to increase understanding of English vocabulary without always depend on the use of dictionaries or also the meaning of words given by the teacher. Word wall picture is an interactive media in the classroom to support listening, speaking, reading and writing.

\section{Literature Review}

\subsection{Word Wall Picture}

Trisnawati (2013) stated that a word wall is a collection of words arranged systematically displayed by using large letters that are affixed to the class wall or other large media in the classroom. The word wall is a tool used not only for display. The word wall is useful for teachers to direct students to a collection of words. Words and key words that are being studied relating to the theme of learning. In line with that Ray (2003) stated that by using the word wall media students are expected increase the understanding of English vocabulary without always depend on the use of the dictionary or the meaning of the word given by the teacher.

While Wasti (2004) explained the purpose of word wall is introducing students to letters, developing students' awareness of letters or phonics, helping students in knowing and writing letter forms, building student ability in connecting sounds and letters, and developing students' skills in spelling and reading.

Lon (2013) explained that the collection of letters was stacked and arranged according to the height of the student so that the student could see it easily and not be over or above his head. Word Wall Picture is one type of instructional media that can improve students' ability in mastery vocabulary.

The Word Wall Picture is an interactive instructional media in the form of a collection of large words and images in the class. It should be used not only affixed and displayed or viewed in the wall, but also can be designed to enhance students' activities and get them fully involve as well as their usage activities to support learning English (listening, speaking, reading and writing). 
Word Wall Picture has three types namely, a) High frequency word wall, b). Frequently Misspelled word wall, c) Subject specific word wall (Lon. 20013). The first word wall type describes activities about letter recognition. The activity of this kind of word wall is often done, namely the understanding of the word form because the memory of the form of a word is often encountered by students, usually students tend to memorize rather than recognize the sounds of letters and combine the letters into syllables. Furthermore, the second type of word wall, ie Frequently-misspelled word wall is a type of word wall that focuses on difficult words that are read and spelled by students. While the third type of word wall is an activity that focuses on the words contained in the subject from within the theme of the subject.

Retzel and Cooter (2003) explained the preparation stage of word wall activity is to begin by making a large cardboard-sized paper, to provide column sections for each letter of the alphabet to be studied, recommend two or three letters each week, by calling and letters. Teacher should be very careful when introducing the letters focus the student's attention about how to write and read the letter, and be sure to use dark markers and letter sizes, enough to be seen from the student seating position when word wall takes place.

There are several ways to make the word wall picture efficient, practical and easy to remember. The several ways are: a). make it easy to remember by using favorite words on a particular theme, b). make it useful by frequently using these words in various listening, speaking, reading or writing activities, c). make it easy to see, by writing it in large letters and affixed to a wall in the classroom.

The principle of this word wall picture is to paste the words and pictures in accordance with the teacher's instructions on the word wall that has been provided. The instructions given by the teacher may be questions or games such as word guessing. The word is written in capital letters with black ink. With the word wall picture encourages students to participate actively in learning and can make students creative and feel happy.

The advantages of word wall picture is practical, easy to do and doesn't take much time while the disadvantages of it is only considered as records, easy to forget and students too often to open the word list in learning process.

\subsection{Linguistic Intelligence}

Linguistic Intelligence is one of the intelligence of Howard Gardner's multiple intelligence theory, everybody is smarter than anyone think. That is the underlying principle of understanding the concept of Multiple Intelligence. The intelligence is most closely related to language development.

According to Gardner linguistic intelligence is the ability to compose the mind clearly and able to use language skills. Linguistic intelligence or language intelligence is the ability to speak both orally and in writing. Linguistic intelligence is very important to communicate well.

Some professions rely heavily on language skills to communicate effectively with many people such as teachers, translators, journalists, writers, etc.

Some students have indicated that they have a prominent linguistic intelligence. Mushfiroh (2008) stated that the following characteristics are easy to learn the language of the conversation. They like to speak in front of the crowd, for example events, speeches, story telling, like to write articles, stories, diaries, poems, like to discuss and respond when listening to other people's conversation and requently recount information obtained from various media and frequent inserts humor in conversation or writing.

Teachers and students communicate using a language. English lesson is always a compulsory subject in schools. The Language Intelligence is the intelligence associated with the ability to perform at the same time to understand information and communication to or from other persons or parties, either orally or in writing.

The characteristics of students who have a prominent linguistic intelligence. They like the language game, for example like to fill the cross word, scrabble, and so on, likes discussion and even smart debate and quickly master a new foreign language, have a good sense of humor and able to 
understand quickly what he heard or read. In a conversation often a lot is inserted with words like "In other words, ......", so instead of using "I mean ....", and so on.

Careers or suitable occupations include being a writer, journalist, lawyer, an organization spokesperson, a language teacher, translator, copywriter, magazine or newspaper editor, TV presenter or radio, and so on. Famous figures are: first Indonesian president Ir. Sukarno, Mark Twain, Charles Dickens, John Grisham, and others.

The ways to improve this linguistic intelligence are by always actively searching for new words in the dictionary. Each student finds a new word, look for the meaning, then try using it with different sentences or contexts, learn the popular words or quotes of famous characters, bring small pocket books at all times to pour your ideas. Learn a new foreign language every five years, and purchase game books like cross words, poetry. Students should listen to the tone, pattern and rhythm of the people around them who are talking and notice why they do it that way.

\subsection{Vocabulary}

Vocabulary is the smallest part of a sentence that has a meaning. Halimah (2011) stated that the word is the smallest unit containing the idea, obtained when the order or a sentence is divided into parts. According to Hamid (1987) the word is morphem or combination which the language is considered the smallest unit that can be declared as a free form, the unit of language can stand alone, consisting of a single morpheme (eg stone and house) or a combination of morphemes (eg : Fighters, following).

Another opinion, Rangkuti (1999) stated that the word is a separate entity and can not be described again. According to Lon (2013) words are utterances that represent a concept or idea. Vocabulary, word, and lexicon are words possessed by a language. Vocabulary is also called lexicon is the word owned by a speaker, writer. There are two lexicons: active lexicon and passive lexicon. Active lexicon is a lexicon that is often used while passive lexicon is rarely used.

Lon (2013) said that vocabulary is defined as all words contained in the language, words controlled by a person or words used by a group of people from the same environment, words used in science, in linguistics, although not all morphemes that exist in one particular language are vocabulary, but most of the morpheme is subjected as a vocabulary, and can be a number of words, phrases, and terms of an alphabetically constrained language with limits and captions.

English: vocabulary is a set of words that are known to mean and can be used by someone in a language. A person's vocabulary is defined as the set of all words the person understands or any words that the person might use to compose a new sentence.

The wealth of a person's vocabulary is generally considered to be a picture of his intelligence or level of education. Understanding vocabulary is generally regarded as an important part of the learning process of a language or the development of a person's ability in a language that has been mastered. Students are often taught new words as part of a particular subject and many adults also consider vocabulary formation as an interesting and educative activity.

Larsen (2003) emphasizes the importance of vocabulary development that is to relate how many vocabularies are mastered by the students with academic language learning materials. He stated that the lack of understanding of vocabulary is the main cause of academic failure.

A research states that the understanding of a text also depends on the size of a vocabulary owned by a person. According to Lon (2013) the ideal vocabulary for beginner learners is between 2,500 and 5,000 words to support language learning. Keraf (2007) stated that the more people master the vocabulary, the more ideas can be expressed.

\section{Methodology}

\subsection{Research Questions/ Hypotheses}

1) Is there a significant difference in learning outcomes of English vocabularies between students who taught by using word wall picture and students taught by using printed media. 
2) Is there an interaction in learning outcomes of English vocabularies on a test comprised of "linguistic intelligence" between students who taught by using word wall picture and students taught by using printed media.

3) Is there higher learning outcomes of English vocabularies for higher linguistic intelligence students who taught by using word wall picture than students taught by using printed media.

4) Is there lower learning outcomes of English vocabularies for lower linguistic intelligence students who taught by using word wall picture than students taught by using printed media

\subsection{Objective of Study}

The purpose of this study is to improve English vocabularies by using word wall picture. There are objectives to be expressed;

1. To find out a significant effect on students' learning outcomes of English vocabularies of those who are taught using word wall picture and students taught using printed media.

2. Which instructional media is better, word wall picture or printed media in enhancing higher learning outcomes of English vocabularies for higher linguistic intelligence students on the fourth grade Elementary School of Al-AzharSyifa Budi,Bekasi, Eastern Jakarta, Indonesia.

\subsection{Research Design}

This study is experimental method. The design used in this research is Factorial Group Design two categories or factorial $2 \times 2$.

Table 1: Factorial 2 x 2 Experiments Research Design

\begin{tabular}{|l|c|c|}
\hline \multicolumn{1}{|c|}{ Instructional Media (A) } & $\begin{array}{c}\text { Word Wall Picture } \\
\left(\mathrm{A}_{1}\right)\end{array}$ & $\begin{array}{c}\text { Printed Media } \\
\left(\mathrm{A}_{2}\right)\end{array}$ \\
\hline Linguistic Intelligence (B) & $\mathrm{A}_{1} \mathrm{~B}_{1}$ & $\mathrm{~A}_{2} \mathrm{~B}_{1}$ \\
\hline High Liguistic Intelligence (B1) & $\mathrm{A}_{1} \mathrm{~B}_{2}$ & $\mathrm{~A}_{2} \mathrm{~B}_{2}$ \\
\hline Low Linguistic Intelligence $\left(\mathrm{B}_{2}\right)$ & & \\
\hline
\end{tabular}

A1: Groups of students taught using Word wall picture

A2: Groups of students taught using printed media

B1: Groups of students who have high linguistic intelligence.

B2: Groups of students who have low linguistic intelligence.

AıB1: Groups of students who have high linguistic intelligence, taught using word wall picture.

$A_{1} B_{2}$ : Groups of students who have low linguistic intelligence, taught using word wall picture.

$\mathrm{A}_{2} \mathrm{~B} 1$ : Groups of students who have high linguistic intelligence, taught using printed media.

$\mathrm{A}_{2} \mathrm{~B}_{2}$ : Groups of students who have low linguistic intelligence, taught using printed media.

\subsection{Population}

The target population in this study were all fourth graders of Elementary School students in Bekasi, East tern Jakarta. Indonesia, while the affordable or measurable population which in real terms became the basis of sampling which is part of the target population in this study were all fourth grade students of Elementary School students Al- AzharSyifa Budi, Bekasi, East tern Jakarta. Indonesia, consisting of five classes totaling 98 students.

\subsection{Sampling Technique}

Sampling Technique in this research by randomly stratified, While to determine the level of linguistic intelligence of students, done by taken a group level of high and low linguistic intelligence using the theory of Guilford Score obtained from the test then ranked. A total of $27 \%$ of the upper group will be expressed as a group of high value. While $27 \%$ of the lower group is expressed as a group that has a low value. 


\subsection{Data Collection Techniques}

Data collection Techniques used in this study consists of two types of instruments namely: 1). Instrument for measuring the English vocabulary learning outcomes. 2). Instrument for measuring students' linguistic intelligence. To measure the English language vocabulary learning outcomes by giving a final test (post - test), While to group of students who have high and low linguistic intelligence are given a questioners.

\subsection{Instrument}

\subsubsection{Validity}

The item analysis is performed by calculating the correlation between the score of the instrument item with the total score, or by seeking the differentiating power of the score of each item from the group providing the visual answer and the low answer, through SPSS software version 21.0 or Product moment.From 40 items, only 35 item is declared valid because $\mathrm{r}$ count is bigger than $\mathrm{r}$ table.

\subsubsection{Reliability}

Reliability test using the Alpha Cronbach method was measured based on the Cronbach Alpha scale of o to 1.The instrument has a visual reliability level if the coefficient value is greater than o.6o. The reliability testing of the instrument can be done by Alpha Cronbach test using SPSS software version 21.0

\subsection{Data Analysis Technique}

Data Analysis Technique used in this research is two dimensional variance analysis or ANAVA 2 (two) path. Before Anava is used, a normality and homogenity test is performed first. The data normality test using SPSS was performed by Kosmogorov-Smirnov test and homogenity test data using SPSS with Levine test

Table 2: Test of Homogeneity of Variances (Variabel $\mathrm{A}_{1} \mathrm{BI}, \mathrm{A}_{2} \mathrm{~B}_{1}, \mathrm{~A}_{1} \mathrm{~B}_{2}$ and $\mathrm{A}_{2} \mathrm{~B}_{2}$ )

\begin{tabular}{|c|c|c|c|}
\hline Levene Statistic & $\mathrm{df}_{1}$ & $\mathrm{df}_{2}$ & Sig. \\
\hline 1.455 & 3 & 52 & .237 \\
\hline
\end{tabular}

Based on table 2 Above shows means sig value of 0.237 greater than the value of $\alpha=0.05$ (0.237> 0.05). Thus Ho is received. Then it can be concluded that data $\mathrm{A}_{1} \mathrm{BI}_{1} \mathrm{~A}_{2} \mathrm{~B}_{1}, \mathrm{~A}_{1} \mathrm{~B}_{2}$ and $\mathrm{A}_{2} \mathrm{~B}_{2}$ homogeneous. Thus the normality and homogeneity requirements of the data have been met and further analysis of variance (ANAVA) in testing the research hypothesis.

\section{4. $\quad$ Research Finding}

Two-way variance analysis is used to examine the main effect and the interaction effect. The main effect on this research is learning with word wall picture and printed media. The interaction effect is the instructional media and linguistic intelligence on the learning outcomes of English vocabulary of fourth grade students of SD Al-Azhar Syifa Budi, Bekasi, Eastern Jakarta. 
Tabel 3: Two Way- Anova: Differences Test of Learning Media Group, Group of Linguistic Intelligence and The influence of Interaction on English Vocabulary Learning Outcomes

\section{Tests of Between-Subjects Effects}

Dependent Variable: Score

\begin{tabular}{|l|c|c|c|c|c|c|}
\hline Source & Type III Sum of Squares & df & Mean Square & F & Sig. & $\begin{array}{c}\underline{F}_{\text {table }} \\
(\mathbf{0 , 0 5 ; 1 , 2 8 )}\end{array}$ \\
\hline Corrected Model & $416.929^{\mathrm{a}}$ & 3 & 138.976 & 24.810 & .000 & \\
Intercept & 46057.786 & 1 & 46057.786 & 8222.184 & .000 & \\
Media & 23.143 & 1 & 23.143 & 4.131 & .047 & 4,02 \\
Linguistic & 200.643 & 1 & 200.643 & 35.819 & .000 & \\
Media * Linguistic & 193.143 & 1 & 193.143 & 34.480 & .000 & \\
Error & 291.286 & 52 & 5.602 & & & \\
Total & 46766.000 & 56 & & & & 4,02 \\
Corrected Total & 708.214 & 55 & & & & \\
\hline
\end{tabular}

a. $\mathrm{R}$ Squared $=.589$ (Adjusted R Squared $=.565$ )

1. The Table 3 shows significant effect of media obtained is smaller than $\alpha=0,05(0,047<0,05)$ and $\mathrm{F}$ value count bigger than $\mathrm{F}$ table $(4,13>4,02)$. Thus $\mathrm{Ho}$ is rejected this means $\mathrm{H1}$ accepted which states that the result of learning English vocabulary as a whole students are taught using word wall picture is higher than students taught by using printed media.

2. The Table 3 shows that the interaction between media and linguistic intelligence is smaller than $\alpha=0,05(0,00<0,05)$ and F value count bigger than F table $(34,48>4,02)$. Thus Ho is rejected this means $\mathrm{H}_{1}$ accepted that states there is interaction in learning outcomes of English vocabularies on a test comprised of "linguistic intelligence" between students who taught by using word wall picture and students taught by using printed media. Because of the significant interaction between variables, the next step performs a test to determine the significance of this interaction by using Anova test followed by the Tukey test required for testing the third hypothesis and the fourth hypothesis, Tukey Test Calculation using SPSS software version 21. The results of the analysis data with Tukey Test can be seen in table 4 .

Table 4: ANOVA-Tukey test calculation result multiple comparisons; Dependent variable: outcomes of English vocabularies score; Tukey HSD

\begin{tabular}{|c|c|c|c|c|c|c|}
\hline \multicolumn{2}{|c|}{ (I) KEL (J) KEL } & \multirow[t]{2}{*}{ Mean Difference (I-J) } & \multirow[t]{2}{*}{ Std. Error } & \multirow[t]{2}{*}{ Sig. } & \multicolumn{2}{|c|}{$95 \%$ Confidence Interval } \\
\hline & & & & & Lower Bound & Upper Bound \\
\hline \multirow[t]{2}{*}{$\mathrm{A} 1 \mathrm{~B}_{1}$} & $\mathrm{~A}_{1} \mathrm{~B}_{2}$ & $7 \cdot 500^{*}$ & .895 & .000 & 5.13 & 9.87 \\
\hline & $\mathrm{A}_{2} \mathrm{~B}_{1}$ & $5.000^{*}$ & .895 & .000 & 2.63 & $7 \cdot 37$ \\
\hline \multirow{3}{*}{$\mathrm{A}_{1} \mathrm{~B}_{2}$} & $\mathrm{~A}_{2} \mathrm{~B}_{2}$ & $5.071^{*}$ & .895 & .000 & 2.70 & 7.45 \\
\hline & $\mathrm{A}_{1} \mathrm{~B}_{1}$ & $-7 \cdot 500^{*}$ & .895 & .000 & -9.87 & -5.13 \\
\hline & $\mathrm{A}_{2} \mathrm{~B} 1$ & $-2.500 *$ & .895 & .035 & -4.87 & -.13 \\
\hline \multirow{3}{*}{$\mathrm{A}_{2} \mathrm{~B} 1$} & $\mathrm{~A}_{2} \mathrm{~B}_{2}$ & $-2.429^{*}$ & .895 & .043 & -4.80 & -.05 \\
\hline & $\mathrm{A}_{1} \mathrm{~B}_{1}$ & $-5.000^{*}$ & .895 & .000 & $-7 \cdot 37$ & -2.63 \\
\hline & $\mathrm{A}_{1} \mathrm{~B}_{2}$ & $2.500^{*}$ & .895 & .035 & .13 & 4.87 \\
\hline \multirow{4}{*}{$\mathrm{A}_{2} \mathrm{~B}_{2}$} & $\mathrm{~A}_{2} \mathrm{~B} 2$ & .071 & .895 & 1.000 & -2.30 & 2.45 \\
\hline & $\mathrm{A}_{1} \mathrm{~B}_{1}$ & $-5.071^{*}$ & .895 & .000 & $-7 \cdot 45$ & -2.70 \\
\hline & $\mathrm{A}_{1} \mathrm{~B}_{2}$ & $2.429^{*}$ & .895 & .043 & .05 & 4.80 \\
\hline & $\mathrm{A}_{2} \mathrm{~B} 1$ & -.071 & .895 & 1.000 & -2.45 & 2.30 \\
\hline
\end{tabular}

\footnotetext{
*. The mean difference is significant at the 0.05 level.
} 
For testing the third hypothesis and the fourth hypothesis, Tukey Test Calculation using SPSS software version 21. The results of the analysis data with Tukey Test can be seen in table 4 .

1. The Table: 4. Above shows the value of sig $=0.00$ is smaller than at sig level $\alpha=0,05$ (o,oo $<0,05)$. Thus Ho is rejected this means $\mathrm{H}_{1}$ accepted which states that the third hypothesis of this study there is higher learning outcomes of English vocabularies for higher linguistic intelligence students who taught by using word wall picture than students taught by using printed media.

2. The table: 4 . Above shows the value of sig $=0.043$ is smaller than the sig level $\alpha=0.05$ (0.043 $<0.05$ ). Thus Ho is rejected this means $\mathrm{H} 1$ accepted which states that the forth hypothesis of this study there is lower learning outcomes of English vocabularies for lower linguistic intelligence students who taught by using word wall picture than students taught by using printed media

\section{Discussion}

Word wall picture that is applied by teacher as one of alternative media of complementary teaching to other learning media is very suitable with teaching material characteristic and elementary school student's age. Using Word wall picture in teaching English vocabulary for beginners, is a very interesting activity for students to memorize new English words. Students are very enthusiastic about learning English using word wall picture, they are directly involved in understanding new words and trying hard to remember them. Characteristics of word wall picture in the form of cards and colorful pictures and can be affixed on the wall, greatly affect the interest of students, especially when held games by dividing the students in two groups, each group has a word wall picture set and the teacher calls a new word, the student must paste the picture on the wall as soon as possible. For the group that can do it first, then the group will get one point. Teacher will mention all new words taught. At the end of this game, the group that can collect the most points, then the group who became champion. Then the teacher will give a reward to the group. The winning group will feel proud and happy. Every hour of English they always ask for games and very enthusiastic in learning. With this, it seems very much that they really enjoy learning English and their motivation increases sharply when using word wall picture.

In addition to the suitability between the characteristics of English vocabulary teaching materials with word wall picture, the success of the implementation using word wall picture was also influenced by the characteristics of students. When viewed from the characteristics of students, individuals with high linguistic intelligence, easily learn the language of the conversation, likes to speak in front of the crowd, such as bringing events, speeches, story telling etc., and often recount information obtained from various media, likes to write articles, stories, diaries, poetry, likes to discuss and respond when listening to other people's talk, likes literary arts such as poetry, prose, declamation, loves role art in drama, comedy, opera, and frequent inserts humor in conversation or writing. Conversely students who have low linguistic intelligence tend to be disliked towards things related to words or language.

\section{Conclusion}

Overall the results of this study indicate that there is influence of usage of word wall picture and linguistic intelligence to learning outcomes of English vocabularies of fourth grade student of AlAzharSyifa Budi, Bekasi, Eastern Jakarta. These learning outcomes are also influenced by external and internal factors. External factors in this study is the use of instructional media tailored to the characteristics of the material. Likewise with internal factors in the form of student characteristics, namely linguistic intelligence is a very important factor to note in the selection and use of appropriate instructional media to achieve optimal learning outcomes. For that if the external factors of instructional media can be organized well by taking into account the internal factors of students, it 
will occur positive educational interaction to achieve the desired changes in learning English vocabulary as well as to improve student motivation in learning English.

\section{References}

Ann s Epstein, (2007).The International TeachersWashintonD.c. national Association for the Education of Young Children.

Azwar, Saifuddin, (2006). Pengantar Psikologi Inteligensi. Edisi I, Cetakan V Yogyakarta: Pustaka Pelajar

Daryanto, EvaluasiPendidikan, (2007). Jakarta: Rineka Cipta

Hamid, Fuad Abdul. (1987).Prosedur Belajar Mengajar Bahasa. Jakarta: Depdikbud,

HalimahAgusliah, (2011). Upaya Peningkatan Kosakatadengan media word wall.

Husein Umar,(2003)Statistika Penelitian, Jakarta Rhineka Cipta.

Keraf.E.Suyanto,Kasihani. (2007). English For Young Learners, Bumi Aksara: Jakarta,

Laser,Freeman. (2003:34). Teaching Language: From Grammar to Grammring, Australia: Heinie.

Lon Wilfong, (2013) Vocabulary strategies that work: Do This-Not that, New York: Eye on Education.

Margaret E Gredler.(2011) Learning and Instruction Teori dan aplikasi. Edisi Keenam, Jakarta: Kencana.

Martini Jamaris ,(2010) orientasi baru dalam Psikologi Pendidikan,Yayasan Penamas Murni.

MuhibbinSyah, (2006) Psikologibelajar: Edisi Revisi 5, Jakarta: PT. Raja Grafindo Persada.

Musfiqon (2012), Pengembangan media dan sumber pembelajaran PT Prestasi Pustakarya Jakarta.

Nana Sudjana,(2005). PenilaianHasil Proses BelajarMengajar, Bandung: PT. Remaja Rosdikarya.

Nasution, S.(1990). Berbagai Pendekatandalam Proses Belajar-Mengaja”, Jakarta: Bina Aksara,.

Musfiroh,Tadkiroatun,(2008). Pengembangan Kecerdasan Majemuk, Jakarta; Universitas Terbuka.

OemarHamalik, (2006). Proses BelajarMengajar. Bandung: Bumi Aksara.

Rangkuti H.Sofia.(1999).Terjemahan dan kaitannya dengan tata Bahasa BahasaInggris, Jakarta: Dian Rakyat.

Ray Reutzeldan Robert B Cooter Jr. (2003).Strategies for Reading Assesment and Instruction New Jersey Merril Prentice hall.

RobertusAngkowo (2002).,Media Pembelajaran, Jakarta: Rineka Cipta.

Robet and Gagne dan Lasile J. Briggs.(1974).Principle of Instructional Design New York: Holt Renehart and Wiston Ins.

Ronald H.Anderson, (1994).Pemilihan dan pengembangan media pembelajaran Jakarta: Raja Grafindo Persada,.

Rusman, (2014)Model-Model Pembelajaran, Jakarta: Rajagrafindo,

SantosoMurwarni, (1999). Statistikaterapan:Tehnik Analisis Data. Jakarta: Program Pasca Sarjana, UNJ.

Slamet. (2003). Belajardan Faktor-faktor yang Mempengaruhinya, Jakarta: PT. Rieneka.

Soedijarto, (1993).Menuju PendidikanNasional yang Relevandan Bermutu Jakarta, Balai Pustaka.

Sudjana,(2010). Metode Statistika, Bandung: Tarsito.

Sugiyono; Metode Penelitian Kuantitatif, Kualitatifdan R\&D; (Penerbit Alfabeta Bandung; 2011).

Suharsimi Arikunto. (2010). Prosedur Penelitian. Jakarta: Penerbit Rineka Cipta, .

Sukardi; (2003). Metodologi Penelitian Pendidikan Kompetensi dan Praktiknya; Penerbit PT. Bumi Aksara; Jakarta.

Supardi (2014), Aplikasi Statistika Dalam Penelitian Penerbit Change Publication; Jakarta..

Tu’u, Tulus (2004). Peran Disiplin Pada Perilaku Dan Prestasi Peserta Didik. Jakarta: Grasindo.

Trisnawati Oka AyuDewa, Suarni Ni Ketut, Marhaeni A.A.I.N, (2013). Pengaruh Metode Pembelajaran visual word wall dan Assesment Project terhadap Kemampuan Kosakata Bahasa Inggris.

Undang,Gunawandkk.(1998).Peningkatan Mutu Proses Belajar Mengajar Sekolah Dasar, Bandung: CV Singer Tengah.

WastiSumanto (2004).,Strategi Pembelajaran, Bandung: PT. Rosda Karya.

Winkel, W.S. (1987).Psikologi Pengajaran, Jakarta: Gramedia.

Yusnaeni Lubis, (1998). Developing Comunicative proficiency in English as a foreign language class, Jakarta: Depdikbud.

http://media.diknas.go.id/media/documen/3537 